\title{
CDK5 Gene
}

National Cancer Institute

\section{Source}

National Cancer Institute. CDK5 Gene. NCI Thesaurus. Code C28530.

This gene is involved in neuronal regulation and is involved in the development of the

mammalian central nervous system. 